\title{
PENGARUH ZEOLIT SEBAGAI AGREGAT KASAR DAN ABU BATUBARA SEBAGAI BAHAN CAMPURAN SEMEN TERHADAP KUAT TEKAN PAVING BLOCK
}

\author{
The Influence of Zeolite as Coarse Aggregate and Fly Ash as Cement \\ Admixture Material on Paving Block's Compressive Strength
}

\author{
INDAH PRATIWI dan EVI D. YANTI \\ UPT Loka Uji Teknik Penambangan dan Mitigasi Bencana, Liwa - LIPI \\ Pekon Padang Dalom Kec. Balik Bukit - Liwa, Kab. Lampung Barat, Propinsi Lampung \\ Telp. (0728) 21631, Fax. (0278) 21630 \\ e-mail : dualima april@yahoo.co.id
}

\begin{abstract}
ABSTRAK
Tingginya permintaan paving block berdampak pada meningkatnya harga dan kebutuhan bahan baku utama yang digunakan. Untuk mengatasinya dibutuhkan material berkualitas baik dan teknologi konstruksi alternatif yang dapat mengurangi ketergantungan terhadap material tertentu. Di Indonesia potensi sumberdaya mineral zeolit dan abu batubara cukup banyak. Kandungan silika dalam abu batubara mencapai $60 \%$ sehingga dapat dimanfaatkan sebagai bahan pengganti semen. Penelitian ini bertujuan untuk mendapatkan komposisi campuran paving block yang memenuhi standar kuat tekan SNI, dengan memanfaatkan zeolit sebagai agregat kasar dan abu batubara sebagai bahan pengganti semen. Benda uji dibuat dengan komposisi campuran yang berbeda yaitu zeolit (agregat kasar), pasir (agregat halus), semen, abu batubara dan air, menggunakan alat cetak tekan manual dan diuji nilai kuat tekannya pada umur 28 hari. Persentase gradasi tiap ukuran butir diatur agar dicapai sifat fisik dan mekanik benda uji yang optimal. Berdasarkan hasil pengujian laboratorium,benda uji paving block ZFA2 memenuhi standar mutu kelas B dengan komposisi campuran zeolit, pasir, semen, abu batubara dan air sebesar 1:2:1,5:3:1 yang dapat digunakan untuk pelataran parkir dengan nilai kuat tekan sebesar 18,09 MPa. Benda uji paving block ZFA4 memenuhi standar mutu kelas C dengan komposisi campuran zeolit, pasir, semen, abu batubara dan air sebesar 1,5:3:1,5:1,5:1 yang cocok digunakan pada lahan pejalan kaki dengan nilai kuat tekan sebesar 15,89 MPa.
\end{abstract}

Kata kunci : Agregat kasar, abu batubara, kuat tekan, paving block, zeolit.

\begin{abstract}
The high demand of paving blocks, has an impact on its rising price and the needs for the main raw materials used. To overcome this problem and reduce the reliance on certain material,, it needs alternative materials and construction technology of good quality Indonesiahas a lot of zeolite and fly ash Silica content of fly ash reachs $60 \%$ so that it can be used as cement replacement material. This study aims to get a mixed composition of paving block that fulfil the compressive strength standard of SNI, by using zeolite as coarse aggregate and fly ash as cement replacement materials. The tests object was made with different mixed composition of zeolite (coarse aggregate), sand (fine aggregate), cement, fly ash and water, by using a manual casting press and then tested for their compressive strength values after 28 days. The percentage of each grain size gradation was set to achieve the optimum physical and mechanical properties of the test object. Based on the laboratory test results, the paving block test object of ZFA2 met the quality standards of class $B$ with a mixed composition of zeolite, sand, cement, fly ash and water 1:2:1.5:3:1 that can be used for parking lot
\end{abstract}


with a value of $18.09 \mathrm{MPa}$ compressive strength. While, the paving block test specimen of ZFA4 met the quality standards of class $C$ with a mixed composition of zeolite, sand, cement, fly ash and water 1.5:3:1,5:1,5:1 that was suitable for pedestrian with the compressive strength of $15.89 \mathrm{Mpa}$.

Keywords : Coarse aggregate, fly ash,compressive strength, paving block, zeolit.

\section{PENDAHULUAN}

Paving block sebagai bahan penutup dan pengerasan lahan sekarang ini sangat banyak digunakan, misalnya untuk trotoar, lahan parkir, bahkan jalan di dalam komplek perumahan. Hal ini disebabkan paving block memiliki beberapa keunggulan di antaranya mudah dalam pemasangandan pemeliharaan, harga yang relatif murah dan memiliki nilai estetika. Tingginya permintaan paving block, berdampak pada meningkatnya harga dan kebutuhan bahan baku utama yang digunakan. Untuk mengatasinya dibutuhkan material berkualitas baik dan teknologi konstruksi alternatif yang dapat mengurangi ketergantungan terhadap material tertentu.

Di Indonesia potensi sumberdaya mineral zeolit dan abu batubara cukup banyak. Di Kabupaten Tanggamus, Propinsi Lampung, sumberdaya zeolit mencapai 41.600.000 ton (Kusdarto, 2008), sedangkan abu batubara banyak dihasilkan di propinsi Sumatera Selatan melalui kegiatan PLTU Bukit Asam, PLTA Keramasan, PT. Semen Baturaja dan kegiatan industri lainnya. Jumlahnya mencapai 12.300 ton/tahun atau 2\% dari total limbah abu batubara yang dihasilkan dalam skala nasional (Yusuf, 2005).

Penggunaan zeolit alam sebesar 10\% dalam pembuatan self-compacting concrete dapat meningkatkan kuat tekan beton berumur 28 hari sebesar $11,22 \%$. Penggunaan zeolit lebih dari $10 \%$ akan menurunkan kuat tekan beton (Poerwadi, Zacoeb dan Syamsudin, 2014). Namun berdasarkan penelitian lainnya, penggunaan zeolit sebesar $20 \%$ dalam pembuatan bata beton ringan, mampu meningkatkan kuat tekan beton dan akan terus meningkat seiring dengan penambahan zeolit (Oktavianita, Syamsudin dan Zacoeb, 2014).

Abu batubara adalah salah satu limbah yang banyak dihasilkan dari pembakaran batubara di PLTU. Abu batubara mengandung unsur kimia antara lain silika $\left(\mathrm{SiO}_{2}\right)$, alumina $\left(\mathrm{Al}_{2} \mathrm{O}_{3}\right)$, feri oksida $\left(\mathrm{Fe}_{2} \mathrm{O}_{3}\right)$ dan kalsium oksida $(\mathrm{CaO})$, juga mengandung unsur tambahan lain yaitu magnesium oksida (MgO), titanium oksida $\left(\mathrm{TiO}_{2}\right)$, alkalin $\left(\mathrm{Na}_{2} \mathrm{O}\right.$ dan $\left.\mathrm{K}_{2} \mathrm{O}\right)$, sulfur trioksida $\left(\mathrm{SO}_{3}\right)$, pospor oksida $\left(\mathrm{P}_{2} \mathrm{O}_{5}\right)$ dan Karbon (C) (Lumbanraja, Alfian dan Muthawali, 2017).

Penggunaan abu batubara sebagai bahan campuran akan mempengaruhi kuat tekan beton. Dalam perencanaan beton High Volume Fly Ash (HVFA), penggunaan abu batubara kelas $\mathrm{C}$ yang memiliki senyawa $\mathrm{CaO}>10 \%$ dalam jumlah yang tinggi, dapat menghasilkan beton dengan kuat tekan yang cukup tinggi, namun semakin besar jumlah abu batubara dalam campuran, maka semakin kecil nilai kuat tekan beton yang dihasilkan Penambahan $30 \%$ abu batubara dalam beton berumur 28 hari memiliki nilai kuat tekan sebesar 24,18 $\mathrm{MPa}$, sedangkan untuk penambahan $70 \%$ abu batubara menghasilkan beton dengan kuat tekan 4,79 MPa (Umboh, Sumajouw dan Windah, 2014).

Penggunaan $25 \%$ abu batubara sebagai pengganti semen dalam beton yang terbuat dari agregat daur ulang mengurangi susut pengeringan yang mengakibatkan kekuatan beton menurun, namun penurunan kekuatan beton tidak terlalu signifikan (Arifi, 2015). Beton yang menggunakan abu batubara lebih sedikit menyerap air dibandingkan dengan beton normal (Solikin, Kholishoh dan Setiawan, 2014), yang artinya abu batubara mengisi ruang-ruang antar agregat menghasilkan beton yang lebih padat, sehingga meningkatkan kekuatan beton.

Penelitian ini bertujuan untuk memanfaatkan zeolit dan limbah abu batubara kelas $F$ hasil pembakaran batubara PLTU untuk pembuatan paving block dengan sasaran menghasilkan benda uji paving block dan komposisi campuran yang memiliki mutu sesuai standar SNI 03-0691-1996 menggunakan zeolit dan abu batubara berdasarkan nilai kuat tekannya (Badan Standardisasi Nasional, 1996). 


\section{METODE}

Benda uji paving block dibuat dari campuran bahan pengikat hidrolis, agregat dan air. Pembuatan benda uji dalam penelitian ini menggunakan agregat kasar dan halus. Persentase dari tiap ukuran agregat ditentukan berdasarkan grafik gradasi ukuran butir berbentuk "S" yang merupakan komposisi gradasi butir ideal untuk memperoleh sifat fisik dan mekanik benda uji yang optimal. Material yang digunakan terdiri dari:

\section{Bahan Pengikat Hidrolis}

1. Semen

Benda uji paving block pada penelitian ini menggunakan semen Portland tipe I dari PT. Semen Baturaja. Berdasarkan SNI No. 15-2049-2004 mengenai Semen Portland, semen Portland tipe I digunakan untuk penggunaan umum yang tidak memerlukan persyaratan-persyaratan khusus seperti yang diisyaratkan pada jenis-jenis lain (Badan Standardisasi Nasional, 2004).

2. Abu Batubara

Komposisi kimia abu batubara dari PLTU Bukit Asam dapat dilihat pada Tabel 1 (Kurniawan $d k k .$, 2010).

Berdasarkan Tabel 1 tersebut, abu batubara PLTU Bukit Asam mengandung senyawa $\mathrm{CaO}$ sebesar 2,92\%. Berdasarkan ASTM C618-08a (2008), abu batubara ini termasuk ke dalam kelas $\mathrm{F}$, dengan nilai senyawa $\mathrm{CaO}<10 \%$. Abu batubara kelas $F$ memiliki sifat pozolaniksehingga dapat digunakan sebagai bahan tambah. Senyawa kimia abu batubara
PLTU Bukit Asam dominan disusun oleh senyawa $\mathrm{SiO}_{2}, \mathrm{Al}_{2} \mathrm{O}_{3}$ dan $\mathrm{Fe}_{2} \mathrm{O}_{3}$ sebesar $60,6 \%, 22,8 \%$ dan 4,12\%. Karena jumlah ketiga senyawa tersebut $>70 \%$, maka abu batubara memenuhi persyaratan kimia spesifikasi abu terbang batubara untuk digunakan dalam beton (Badan Standardisasi Nasional, 2014).

Tabel 1. Komposisi kimia abu batubara PLTU Bukit Asam (Kurniawan $d k k ., 2010)$

\begin{tabular}{cccc}
\hline Komponen & Nilai (\%) & Komponen & Nilai (\%) \\
\hline $\mathrm{SiO}_{2}$ & 60,6 & $\mathrm{TiO}_{2}$ & 0,75 \\
$\mathrm{Al}_{2} \mathrm{O}_{3}$ & 22,8 & $\mathrm{MnO}$ & 0,053 \\
$\mathrm{Fe}_{2} \mathrm{O}_{3}$ & 4,12 & $\mathrm{P}_{2} \mathrm{O}_{5}$ & 0,66 \\
$\mathrm{~K}_{2} \mathrm{O}$ & 0,46 & $\mathrm{LOI}$ & 0,66 \\
$\mathrm{Na}_{2} \mathrm{O}$ & 1,33 & $\mathrm{H}_{2} \mathrm{O}$ & 2,2 \\
$\mathrm{CaO}$ & 2,92 & $\mathrm{~S}$ Total & 0,32 \\
$\mathrm{MgO}$ & 1,38 & & \\
\hline
\end{tabular}

\section{Agregat}

Agregat yang digunakan dalam pembuatan benda uji terdiri dari agregat kasar dan halus. Agar diperoleh sifat fisik dan mekanik yang optimal, maka komposisi ukuran butir matrik atau agregat perlu mengacu pada komposisi ideal, yaitu gradasi ukuran butir menyerupai bentuk "S" (Agustinus, 2007). Penentuan komposisi ukuran butir ideal dilakukan dalam beberapa langkah. Pertama, menentukan persentase distribusi ukuran butir yang lolos tiap ukuran ayakan seperti pada Tabel 2 . Selanjutnya, data pada Tabel 2 digambarkan dalam grafik distribusi ukuran butir (Gambar 1).

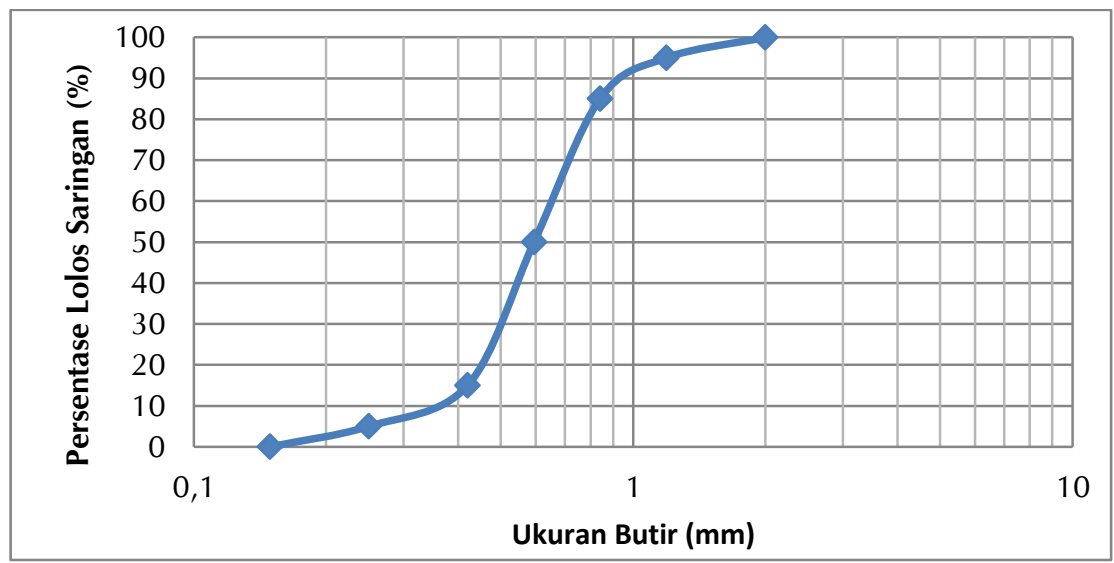

Gambar 1. Grafik distribusi ukuran butir berbentuk "S" (Agustinus, 2007) 
Grafik distribusi ukuran butir merupakan grafik perbandingan antara ukuran butir dalam satuan milimeter dengan persentase agregat lolos saringan dengan ukuran tertentu. Apabila kurva yang dibuat berdasarkan data pada Tabel 2 sudah membentuk dan menyerupai huruf " $\mathrm{S}$ ", maka persentase distribusi ukuran butir yang telah ditentukan sebelumnya merupakan komposisi yang sudah tepat dan ideal. Namun apabila kurva belum menyerupai huruf " $\mathrm{S}$ ", maka nilai-nilai persentase agregat yang lolos tiap saringan harus diubah sampai kurva "S" didapatkan.

Tabel 2. Persentase distribusi ukuran butir

\begin{tabular}{ccc}
\hline $\begin{array}{c}\text { Klasifikasi } \\
\text { Ukuran Matrik }\end{array}$ & $\begin{array}{c}\text { Ukuran Ayakan } \\
(\text { mesh })\end{array}$ & $\%$ \\
\hline \multirow{2}{*}{ Kasar (zeolit) } & $-10+16$ & 5 \\
& $-16+20$ & 10 \\
\hline \multirow{3}{*}{ Halus (pasir } & $-20+30$ & 35 \\
sungai) & $-30+40$ & 35 \\
& $-40+60$ & 10 \\
& -60 & 5 \\
\hline & Total & 100 \\
\hline
\end{tabular}

Karena kurva "S" telah tercapai (Gambar 1), maka benda uji paving block dibuat dengan agregat berikut, yaitu :

\section{Agregat kasar}

Agregat kasar berupa butiran-butiran kecil zeolit berasal dari Kabupaten Tanggamus. Mineral zeolite dari daerah ini berjenis klinoptilolit dan mordenit (Yanti, 2015). Agregat kasar yang digunakan merupakan agregat yang berukuran $-10+16$ mesh dan $-16+20$ mesh, masing-masing sebesar $5 \%$ dan $10 \%$ dari berat total agregat dalam campuran.

\section{Agregat halus}

Agregat halus merupakan pasir sungai berasal dari sungai Way Semangko, Kabupaten Lampung Barat dengan butir berukuran $-20,-30,-40$ dan -60 mesh. Masing-masing sebesar 35\%, 35\%, 10\% dan $5 \%$ dari berat total agregat dalam campuran.

\section{Air}

Air yang digunakan merupakan air dari PDAM Limau Kunci, Lampung Barat.

Dalam penelitian ini, abu batubara digunakan sebagai bahan pengganti semen dengan persentase tertentu berdasarkan perbandingan terhadap volume semen. Abu batubara dicampur dengan semen, dan zeolit dicampur dengan pasir sebagai agregat. Selanjutnya campuran semen dan abu batubara disatukan dengan agregat dan diaduk dengan menggunakan sendok semen sambil ditambahkan air sampai terbentuk adukan yang homogen. Benda uji dibuat dengan variasi campuran bahan baku yang berbeda seperti pada Tabel 3. yang memperlihatkan perbandingan komposisi campuran bahan baku untuk pembuatan benda uji paving block dalam satuan volume. Jumlah semen dalam tiap variasi campuran adalah tetap, sedangkan jumlah agregat, abu batubara dan air berubahubah.

Benda uji dicetak menggunakan alat tekan manual (Gambar 2) akan menghasilkan paving block dengan permukaan lebih rapat apabila dibandingkan dengan paving block yang dibuat dengan alat tekan bertenaga mesin (Müller dkk., 2006).

Tabel 3. Komposisi campuran bahan baku benda uji paving block

\begin{tabular}{|c|c|c|c|c|c|}
\hline \multirow[b]{2}{*}{ Kode } & \multicolumn{2}{|c|}{ Agregat (I) } & \multirow[b]{2}{*}{ Semen } & \multirow[b]{2}{*}{$\begin{array}{c}\text { Abu } \\
\text { batubara }\end{array}$} & \multirow[b]{2}{*}{ Air } \\
\hline & $\begin{array}{l}\text { Zeolit } \\
\text { (Kasar) }\end{array}$ & $\begin{array}{c}\text { Pasir } \\
\text { (Halus) }\end{array}$ & & & \\
\hline ZFA1 & 2 & 1 & 1,5 & 3 & 0,5 \\
\hline ZFA2 & 1 & 2 & 1,5 & 3 & 1 \\
\hline ZFA3 & 3 & 1,5 & 1,5 & 1,5 & 0,5 \\
\hline ZFA4 & 1,5 & 3 & 1,5 & 1,5 & 1 \\
\hline
\end{tabular}




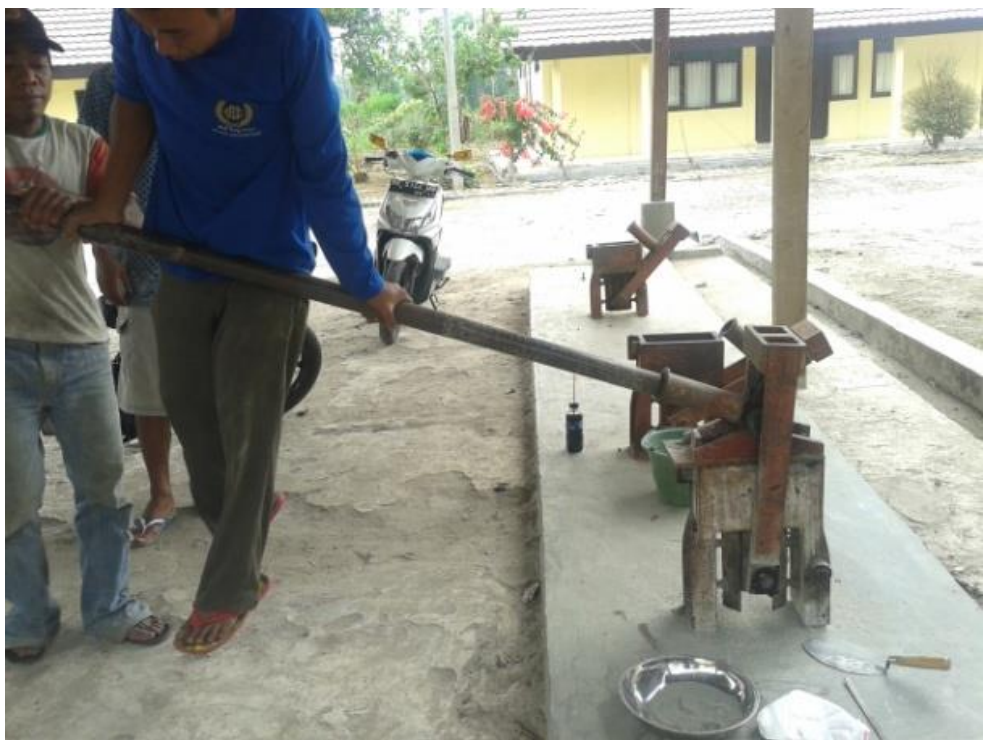

Gambar 2. Alat cetak tekan manual paving block

\section{Kualitas Paving Block}

Penggunaan paving block berdasarkan mutu telah ditetapkan oleh SNI 03-0691-1996 mengenai paving block. Kualitas paving block dibagi menjadi 4 kelas mutu. Karakteristik dari tiap mutu dibagi berdasarkan nilai kuat tekan dan ketahanan ausnya. Masing-masing kelas mutu diaplikasikan untuk penggunaan yang berbeda-beda seperti pada Tabel 4 .

Mutu A

Kualitas paving block yang paling baik, dapat digunakan untuk perkerasan jalan yang dilalui kendaraan roda dua maupun empat, misal jalan-jalan di komplek perumahan, mampu menahan beban rata-rata hingga $40 \mathrm{MPa}$, ketahanan ausnya mencapai $0,09 \mathrm{~mm} /$ menit.

\section{Mutu B}

Kualitas paving block kedua yang digunakan untuk perkerasan pelataran parkir kendaraan. Beban yang dapat ditahan rata-rata sebesar 20 Mpa dengan ketahanan aus rata-rata sebesar $0,13 \mathrm{~mm} /$ menit.

\section{Mutu C}

Merupakan mutu paving block yang mampu menahan beban pejalan kaki, biasa digunakan untuk trotoar atau pedestrian. Mampu menahan beban rata-rata sebesar $15 \mathrm{MPa}$ dan memiliki ketahanan aus rata-rata sebesar 0,16 $\mathrm{mm} / \mathrm{menit}$.

\section{Mutu D}

Merupakan mutu paving block paling rendah yang hanya dapat menahan beban rata-rata maksimal $10 \mathrm{MPa}$. Biasa digunakan untuk taman dan perkerasan lahan ringan lainnya. Ketahanan ausnya rata-rata sangat rendah yaitu sebesar $0,219 \mathrm{~mm} /$ menit.

\section{HASIL DAN PEMBAHASAN}

Kekuatan tekan adalah kemampuan blok beton atau beton untuk menerima gaya tekan per satuan luas. Pengujian kuat tekan dilakukan oleh Balai Besar Bahan dan Barang Teknik (B4T) Bandung berdasarkan standar (SNI 03-0691-1996) terhadap setiap komposisi campuran yang terdiri dari 10 buah benda uji masing-masing dipotong berbentuk kubus dan rusuk-rusuknya disesuaikan dengan ukuran benda uji.

Benda uji yang telah siap, ditekan hingga hancur. Arah penekanan pada benda uji disesuaikan dengan arah tekanan beban dalam pemakaiannya. Kuat tekan rata-rata dari benda uji paving block dihitung dari jumlah kuat tekan dibagi jumlah benda uji. Dari pengujian laboratorium terhadap benda uji paving block dengan komposisi campuran yang berbeda berumur 28 hari, maka didapat nilai kuat tekan seperti pada Tabel 5. 
Tabel 4. Kualitas paving berdasarkan SNI 03-0691-1996 (Badan Standardisasi Nasional, 1996)

\begin{tabular}{cccccc}
\hline \multirow{2}{*}{ Mutu } & \multicolumn{2}{l}{ Kuat tekan (MPa) } & \multicolumn{2}{c}{ Ketahanan aus $(\mathrm{mm} / \mathrm{menit})$} & \multirow{2}{*}{ Penggunaan } \\
\cline { 2 - 5 } & Rata-rata & Min. & Rata-rata & Maks. & Jalan \\
A & 40 & 35 & 0,09 & 0,103 & Pelataran parkir \\
B & 20 & 17 & 0,13 & 0,149 & Pejalan kaki \\
C & 15 & 12,5 & 0,16 & 0,184 & Taman dan penggunaan lain \\
D & 10 & 8,5 & 0,219 & 0,251 & \\
\hline
\end{tabular}

Tabel 5. Hasil pengujian kuat tekan benda uji paving block umur 28 hari

\begin{tabular}{|c|c|c|c|c|c|c|}
\hline \multirow[b]{2}{*}{ Kode } & \multicolumn{2}{|c|}{ Agregat } & \multirow[b]{2}{*}{ Semen } & \multirow{2}{*}{$\begin{array}{c}\text { Abu } \\
\text { batubara }\end{array}$} & \multirow[b]{2}{*}{ Air } & \multirow{2}{*}{$\begin{array}{c}\text { Kuat Tekan } \\
\text { (MPa) }\end{array}$} \\
\hline & $\begin{array}{c}\text { Zeolit } \\
\text { (Coarse) }\end{array}$ & $\begin{array}{l}\text { Pasir } \\
\text { (Fine) }\end{array}$ & & & & \\
\hline ZFA1 & 2 & 1 & 1,5 & 3 & 0,5 & 5,93 \\
\hline ZFA2 & 1 & 2 & 1,5 & 3 & 1 & 18,09 \\
\hline ZFA3 & 3 & 1,5 & 1,5 & 1,5 & 0,5 & 8,29 \\
\hline ZFA4 & 1,5 & 3 & 1,5 & 1,5 & 1 & 15,89 \\
\hline
\end{tabular}

Benda uji paving block yang memenuhi standar mutu kualitas paving block SNI 030691-1996 adalah benda uji paving block dengan kode ZFA2 dan ZFA4. Benda uji ZFA2 memenuhi standar mutu kelas $B$ yang dapat digunakan untuk pelataran parkir dengan nilai kuat tekan sebesar 18,09 MPa, sedangkan benda uji ZFA4 memenuhi standar mutu kelas C yang dapat digunakan pada lahan untuk pejalan kaki dengan nilai kuat tekan sebesar 15,89 MPa.

Berdasarkan hasil pengujian kuat tekan pada benda uji, benda uji ZFA2 dengan komposisi campuran zeolit, pasir, semen, abu batubara dan air sebesar 1:2:1,5:3:1 merupakan komposisi campuran paling baik dalam memanfaatkan zeolit sebagai agregat kasar dan abu batubara sebagai bahan pengganti semen.

Kuat tekan dipengaruhi oleh jumlah air yang digunakan dalam campuran. Benda uji ZFA1 dan ZFA3 menggunakan air lebih sedikit yaitu sebanyak 0,5 Liter sedangkan benda uji ZFA2 dan ZFA4 menggunakan air sebanyak 1 Liter. Air merupakan salah satu komponen dalam terjadinya proses hidrasi. Kurangnya jumlah air mengakibatkan proses hidrasi tidak berlangsung optimal sehingga menyisakan komponen semen yang tidak bereaksi. Proses hidrasi yang tidak optimal menyebabkan kekuatan benda uji menurun. Jumlah air yang berlebih akan menyebabkan banyaknya gelembung air yang terbentuk setelah proses hidrasi selesai. Gelembung air nantinya akan menjadi pori yang menyebabkan kekuatan benda uji juga menurun.

Rendahnya kekuatan benda uji juga disebabkan oleh penggunaan zeolit sebagai agregat kasar. Berdasarkan hasil penelitian sebelumnya (Safitri dan Djumari, 2009), untuk paving block yang hanya menggunakan campuran antara semen sebagai bahan pengikat dan pasir sebagai agregat dengan perbandingan 1:2 dan 1:3 kuat tekannya mencapai 32,9 MPa dan 22,8 MPa.

Sedangkan benda uji yang menggunakan zeolit sebagai agregat kasar dengan komposisi perbandingan antara bahan pengikat dan agregat yang sama, kuat tekan maksimumnya hanya mencapai 18,09 MPa dan 15,89 MPa.

Zeolit alam memiliki sifat adsorpsi tinggi karena mempunyai porositas terbuka yang besar dalam struktur kristalnya yang memungkinkan satu lubang besar untuk penyerapan (Kusdarto, 2008). Sebagian air yang digunakan dalam campuran masuk ke dalam pori-pori zeolit. Semakin banyak zeolit yang digunakan maka air yang digunakan untuk proses hidrasi semakin berkurang sehingga menyebabkan penurunan kekuatan benda uji.

Penggunaan agregat kasar yang lebih banyak dibandingkan dengan agregat halus dalam campuran menyebabkan penurunan kekuatan benda uji. Hal ini disebabkan oleh banyaknya jumlah ruang antar butir agregat kasar yang 
terbentuk, sehingga benda uji lebih rapuh dan memiliki kekuatan lebih kecil.

Penggunaan abu batubara yang lebih banyak dalam campuran menghasilkan benda uji dengan kekuatan lebih besar. Benda uji ZFA2 dengan perbandingan antara semen dan abu batubara sebesar 1:2 memiliki kuat tekan lebih besar dibandingkan dengan benda uji ZFA4 dengan perbandingan 1:1. Penambahan abu batubara sebesar $100 \%$ terhadap volume semen dapat meningkatkan kuat tekan sebesar 2,2 MPa atau naik sebesar $13,85 \%$. Hal ini disebabkan oleh kandungan silikat $\left(\mathrm{SiO}_{2}\right)$ aktif dalam abu batubara akan bereaksi dengan kalsium hidroksida $\left(\mathrm{Ca}(\mathrm{OH})_{2}\right)$ yang dibebaskan dari proses hidrasi antara semen dan air untuk membentuk kalsium silikat hidrat $(\mathrm{CSH})$, sehingga beton yang dihasilkan akan lebih padat dan kekuatan atau mutunya bertambah (Safitri dan Djumari, 2009).

Peningkatan kuat tekan benda uji juga dipengaruhi oleh ukuran butiran abu batubara yang berkisar antara 0,5-100 $\mu \mathrm{m}$ (Kurniawan $d k k ., 2010)$, yang dapat mengisi ruang antar butiran agregat pada benda uji, sehingga benda uji menjadi lebih padat dan kekuatannya meningkat.

\section{KESIMPULAN}

Berdasarkan hasil penelitian dapat disimpulkan bahwa benda uji paving block ZFA2 dan ZFA4 masing-masing memenuhi standar mutu kelas B dan C yang dapat digunakan pada pelataran parkir dan lahan untuk pejalan kaki. Komposisi campuran terbaik dalam pemanfaatan zeolit dan abu batubara adalah pada benda uji ZFA2 yang menggunakan campuran zeolit, pasir, semen, abu batubara dan air sebesar 1:2:1,5:3:1, dengan nilai kuat tekan mencapai 18,09 MPa. Penggunaan abu batubara dalam campuran dapat mengurangi ketergantungan terhadap semen karena kandungan kimianya yang mirip dengan semen, terlihat dari pengaruh penggunaannya terhadap kenaikan nilai kuat tekan sebesar $13,85 \%$ dengan penambahan $100 \%$ abu batubara terhadap volume semen.

Untuk penelitian selanjutnya, hendaknya mengacu pada komposisi campuran zeolit, pasir, semen, abu batubara dan air sebesar
$1: 2: 1,5: 3: 1$ yang dimodifikasi dengan variasi komposisi lain, untuk mendapatkan hasil yang lebih baik.

\section{UCAPAN TERIMAKASIH}

Atas kontribusi dan bantuannya dalam penulisan artikel ini, penulis mengucapkan banyak terimakasih kepada Kepala UPT LUTPMB Liwa serta rekan-rekan yang ikut berpartisipasi dalam kegiatan penelitian "Pemanfaatan zeolit dan abu batubara pada pembuatan bata beton" Balai Besar Bahan dan Barang Teknik (B4T) Bandung atas bantuannya dalam pengujian laboratorium. Para reviewer yang telah memberikan komentar dan masukan dalam penulisan artikel ini.

\section{DAFTAR PUSTAKA}

Agustinus, E. T. S. (2007) “Bata keramik suhu bakar rendah sebagai bahan bangunan konstruksi ringan," in Prosiding Seminar Geoteknologi, Kontribusi Ilmu Kebumian Dalam Pembangunan Berkelanjutan. Bandung: Pusat Penelitian Geoteknologi-LIPI, pp. 207-214. Available at:

http://jrisetgeotam.com/index.php/proceeding s/article/viewFile/914/pdf.

Arifi, E. (2015) "Pemanfaatan fly ash sebagai pengganti semen parsial untuk meningkatkan performa beton agregat daur ulang," Rekayasa Sipil, 9(3), pp. 229-235. Available at:

http://rekayasasipil.ub.ac.id/index.php/rs/articl e/view/317.

ASTM C618-08a (2008) "Standard specification for coal fly ash and raw or calcined natural pozzolan for use in concrete." ASTM International.

Badan Standardisasi Nasional (1996) SNI 03-06911996: Bata beton (paving block). Available at: http://puskim.pu.go.id/wpcontent/uploads/2017/07/SNI-03-06911996.pdf.

Badan Standardisasi Nasional (2004) SNI 15-20492004: Semen Portland. Available at: https://dwikusumadpu.files.wordpress.com/20 13/03/21376_sni_15-2049-2004-semenportland.pdf. 
Badan Standardisasi Nasional (2014) SNI 2460, 2014: Spesifikasi abu terbang batubara dan pozolan alam mentah atau yang telah dikalsinasi untuk digunakan dalam beton. Available at:

http://nspkjembatan.pu.go.id/public/uploads/T ahapPelaksanaan/SNI/1510487898(277)_sni_ 2460-2014.pdf.

Kurniawan, A. R., Adenan, D. D., Untung, S. R. Hadijah, N. R. and Alimano, M. (2010) Penelitian pemanfaatan abu batubara PLTU untuk penimbunan pada pra reklamasi tambang batubara. Bandung: Puslitbang tekMIRA.

Kusdarto (2008) "Potensi zeolit di Indonesia," Jurnal Zeolit Indonesia, 7(2), pp. 78-87. Available at:

https://izindo.files.wordpress.com/2014/12/jzi -vol-7-no-2-2008.pdf.

Lumbanraja, S., Alfian, Z. and Muthawali, D. I. (2017) "Penggunaan dan pemanfaatan kembali batubara sebagai material bangunan," Jurnal Stikna, 1(1), pp. 83-94. Available at:

http://jurnal.stikna.ac.id/index.php/stikna/artic le/view/15.

Müller, C., Fitriani, E., Halimah and Febriana, I. (2006) Modul pelatihan pembuatan ubin atau paving blok dan batako. Jakarta: International Labour Office. Available at:

https://www.ilo.org/jakarta/whatwedo/publica tions/WCMS 124018/lang--en/index.htm.

Oktavianita, Y., Syamsudin, R. and Zacoeb, A. (2014) "Perbandingan kuat tekan dan tegangan-regangan bata beton ringan dengan penambahan mineral alami zeolit alam bergradasi tertentu dengan dan tanpa perawatan khusus," Jurnal Mahasiswa Jurusan Teknik Sipil, 1(3), pp. 1-8. Available at: http://sipil.studentjournal.ub.ac.id/index.php/j mts/article/view/161.

Poerwadi, M. R., Zacoeb, A. and Syamsudin, R. (2014) "Pengaruh penggunaan mineral lokal zeolit alam terhadap karakteristik selfcompacting concrete (SCC)," Jurnal Mahasiswa Jurusan Teknik Sipil, 1(4), pp. 110. Available at: http://sipil.studentjournal.ub.ac.id/index.php/j mts/article/view/82.

Safitri, E. and Djumari (2009) "Kajian teknis dan ekonomis pemanfaatan limbah batubara (fly ash) pada produksi paving block," Media Teknik Sipil, 9(1), pp. 36-40. Available at: http://puslit2.petra.ac.id/ejournal/index.php/m ts/article/view/17804.

Solikin, M., Kholishoh, S. and Setiawan, B. (2014) "Pengaruh perbedaan sumber fly ash terhadap karakteristik mekanik high volume fly ash concrete yang dibuat dengan menggunakan semen PPC," Jurnal Eco Rekayasa, 10(2), pp. 111-116. Available at:

https://publikasiilmiah.ums.ac.id/handle/1161 $7 / 5184$.

Umboh, A. H., Sumajouw, M. D. J. and Windah, R. S. (2014) "Pengaruh pemanfaatan abu terbang (fly ash) dari PLTU II Sulawesi Utara sebagai substitusi parsial semen terhadap kuat tekan beton," Jurnal Sipil Statik, 2(7), pp. 352-358. Available at: https://ejournal.unsrat.ac.id/index.php/jss/artic le/view/6006.

Yanti, E. D. (2015) Studi karakteristik zeolit Tengor - Lampung pada pemanfaatan mineral silikat alam. Institut Teknologi Bandung.

Yusuf, M. (2005) "Pengaruh penambahan aktifator terhadap kualitas semen pozolan kapur dari abu batubara," Jurnal Rekayasa Sriwijaya, 10(3), pp. 52-56. 